\section{Chemically Controlling Root Escape in Pot-in- pot Production of River Birch and Yoshino Cherry}

\section{J. Roger Harris ${ }^{1}$,}

Alex X. Niemiera ${ }^{2}$,

Robert D. Wright ${ }^{3}$, and

Charles H. Parkerson ${ }^{4}$

Additional index words. Betula nigra, 'Heritage', Prunus $\times$ yedoensis, Biobarrier, trifluralin, container production, circling roots, Keeper Upper, trees

Summary. Three experiments were conducted to determine the feasibility of using Biobarrier, a landscape fabric with trifluralin herbicide-impregnated nodules, of various sizes to prevent root escape of trees from the drainage holes of 56-liter containers in belowground pot-in-pot (P\&P) and aboveground Keeper Upper (KU) nursery production systems. In addition, side holes or slits were cut in some container walls to test the effect of Biobarrier on the prevention of circling roots. In Expt. 1 (P\&P), Betula nigra L. 'Heritage' (river birch) trees with no Biobarrier had root ratings for roots escaped through drainage holes that indicated a 5 -fold increase in numbers of roots than for treatments containing Biobarrier. All Biobarrier treatments reduced root

${ }^{1}$ Assistant professor, Department of Horticulture, 301 Saunders Hall, Virginia Polytechnic and State University, Blacksburg, VA 24061

${ }^{2}$ Associate professor, Department of Horticulture, 301 Saunders Hall, Virginia Polytechnic and State University, Blacksburg, VA 24061.

${ }^{3}$ Professor, Department of Horticulture, 301 Saunders Hall, Virginia Polytechnic and State University, Blacksburg, VA 24061.

${ }^{4}$ President, Lancaster Farms Nursery, Inc. 5800 Knotts Neck Road, Suffolk, VA 23436,

Use of trade names does not imply endorsement of the products named or criticism of similar ones not named. The cost of publishing this paper was defrayed in part by the payment of page charges. Under postal regulations, this paper therefore must be hereby marked advertisement solely to indicate this fact. escape and resulted in commercially acceptable control. In Expt. 2 (KU), control and the Biobarrier treatment river birch trees (30 nodules) had commercially unacceptable root escape. In Expt. 3 (P\&P), control and 10-nodule treatment Prunus $\times$ yedoensis Matsum. (Yoshino cherry) trees had commercially unacceptable root escape, but treatments containing 20 and 40 nodules resulted in commercially acceptable control. Biobarrier did not limit shoot growth in any of the experiments. The results of these experiments indicate that Biobarrier did not prevent circling roots, but sheets containing at least 8 or 20 nodules of trifluralin acceptably prevented root escape from drainage holes in the pot-in-pot production of 56-liter container river birch trees and Yoshino cherry trees, respectively.

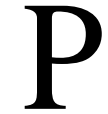
arkerson (1990) recently promoted a system of container tree production that is currently being used by an increasing number of nurseries. This system, known as pot-in-pot (P\&P), consists of a permanent socket container that is placed into the ground with the top lip about $5 \mathrm{~cm}$ above grade and a plantgrowing container that is placed within the socket container and removed along with the tree at harvest (Fig. 1). The $\mathrm{P} \& \mathrm{P}$ system surmounts many of the limitations of conventional aboveground container production such as the need for winter protection structures, supra optimal root-zone temperatures, and container windthrow. Temperatures of $-11 \mathrm{C}$ at the Virginia Tech P\&P nursery resulted in no discernible winter injury on nonprotected trees such as Acer saccharum Marsh. (sugar maple), Quercus rubrum L. (red oak), and Laburnum $\times$ wateri (Kirchn.) Dipp. (unpublished data). Ruter (1993) found that root-zone temperatures were lower during summer months and root growth was greater on P\&Pgrown Lagerstroemia indica $\times$ fauriei 'Natchez', Ilex $\times$ attenuata 'Savannah" and Magnolia $\times$ soulangiana compared to conventional above-ground container-grown trees.

One of the major production concerns with the $\mathrm{P} \& \mathrm{P}$ system is root escape through the drainage holes (Fig. 1) (Yeager et al., 1994; Ruter, 1994). Roots often grow through the dark humid space between the growing and 


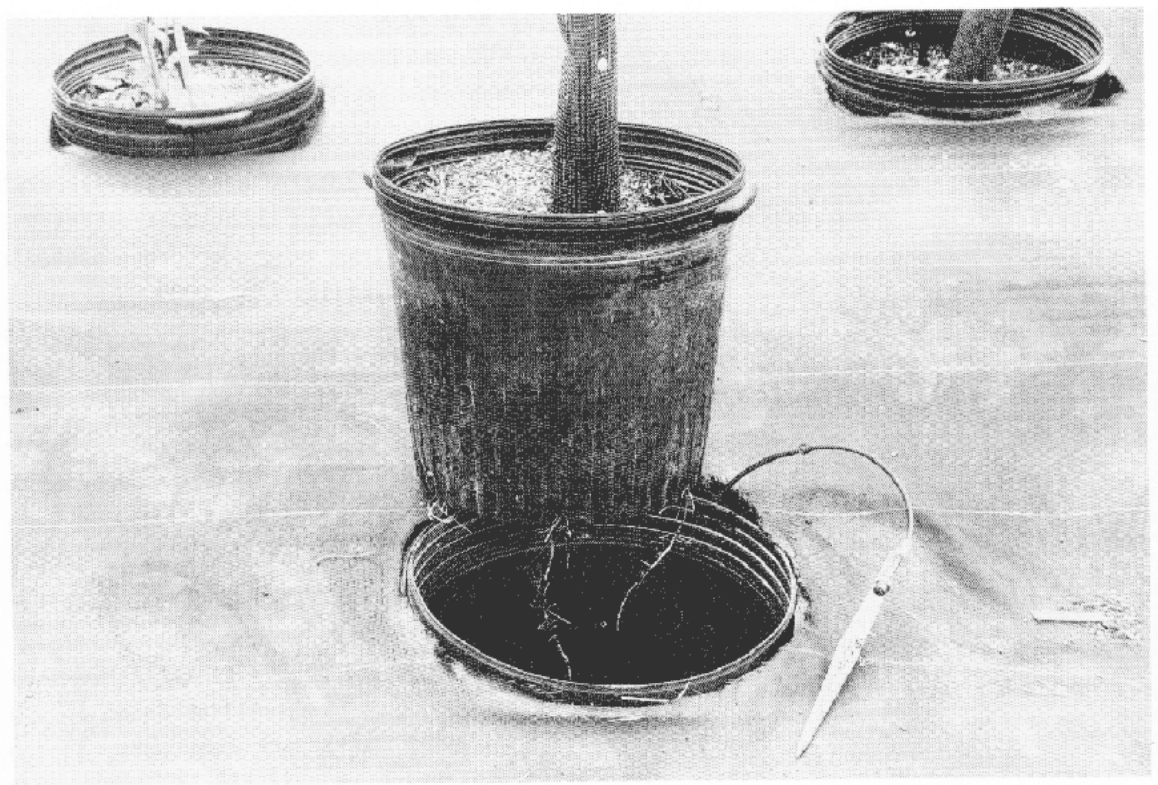

the socket containers and into the ground below. In such cases, harvest is problematical, and the socket pot often is destroyed. Breaking these roots at harvest could result in plant water stress, especially when trees are harvested in leaf. Biobarrier (Remay, Old Hickory, Tenn.) is Typar geotextile fabric with nodules impregnated with time-released trifluralin herbicide (Fig. 2 ). The trifluralin volatilizes and prevents root elongation at concentrations of $7.6 \mathrm{ppm}$ or greater in the soil air space (promotional literature, Remay). Biobarrier is an effective barrier to tree roots when applied in sheets in the soil (Knight et al., 1992) and initially was marketed as a barrier to tree roots that may disturb sidewalks, landfill barriers, septic fields, etc. Ruter (1994) showed that Biobarrier sheets could prevent root escape effectively on Lagerstroemia indica $\times$ faurie $i$ 'Acoma' growing in 28-liter P\&P containers when sheets containing 234 nodules per socket pot were used. However, height and shoot dry weight were lower compared to nontreated $\mathrm{P} \& \mathrm{P}$ trees.

Another recently developed production system uses an above-ground shell [Keeper Upper (KU), Lerio, Mobile, Ala.] that potentially buffers container temperatures and prevents windthrow. This system has possible utility for use when high water tables or poorly drained soils prevent economical installation of the P\&P system. The shell has the form of a squarebased, bottomless, flat-topped pyra- mid, with an opening for a plantgrowing container and two ventilation holes on the top edge (Fig. 3). This system essentially resembles an aboveground $\mathrm{P} \& \mathrm{P}$ system.

The purpose of this research was to. investigate the effect of sheets of Biobarrier containing various numbers of trifluralin herbicide nodules on root escape of 56-liter $\mathrm{P} \& \mathrm{P}$ river birch and Yoshino cherry and 56-liter KU river birch. In addition, the potential for a concomitant prevention of circling roots, thought by some to limit posttransplant success (Appleton, 1993; Warren and Blazich, 1991), was tested by cutting slits or drilling holes in a
Fig. 1. A 56-liter pot-in-pot system showing typical early stage of root escape through container drainage holes.

vertical line on opposing sides of growing container sidewalls.

\section{Materials and methods}

Plant material. Plant material used in Expts. 1 and 2 was 3- to 4-m multistem (three stems per plant) Betula nagra 'Heritage' (river birch), obtained from J. Frank Schmidt and Sons, Boring, Ore. Trees were fall dug and held in winter storage until shipment to the experimental site at Lancaster Farms Nursery, Suffolk, Va. Plant materials used in Expt. 3 were 1.2 to $1.5 \mathrm{~m}$ Prunus $\times$ yedoensis (Yoshino cherry), grown in 12-liter containers at the Virginia Tech nursery in Blacksburg, Va.

Experiment 1. Bare-root river birch liners were planted into 56-liter containers (no. 15, Lerio) in $100 \%$ milled pine bark substrate in mid-February 1994, at Lancaster Farms Nursery, Suffolk, Va. All trees then were put into $\mathrm{P} \& \mathrm{P}$ production in a completely random statistical design with 16 replicates of 5 treatments. Each treatment except controls included a double row of 6.5-mm-diameter holes, drilled through the plant-growing container walls and evenly spaced about $1 \mathrm{~cm}$ apart, beginning $5 \mathrm{~cm}$ from the bot-

Fig. 2. Biobarrier sheets with 8,16 , and 32 nodules of trifluralin. 


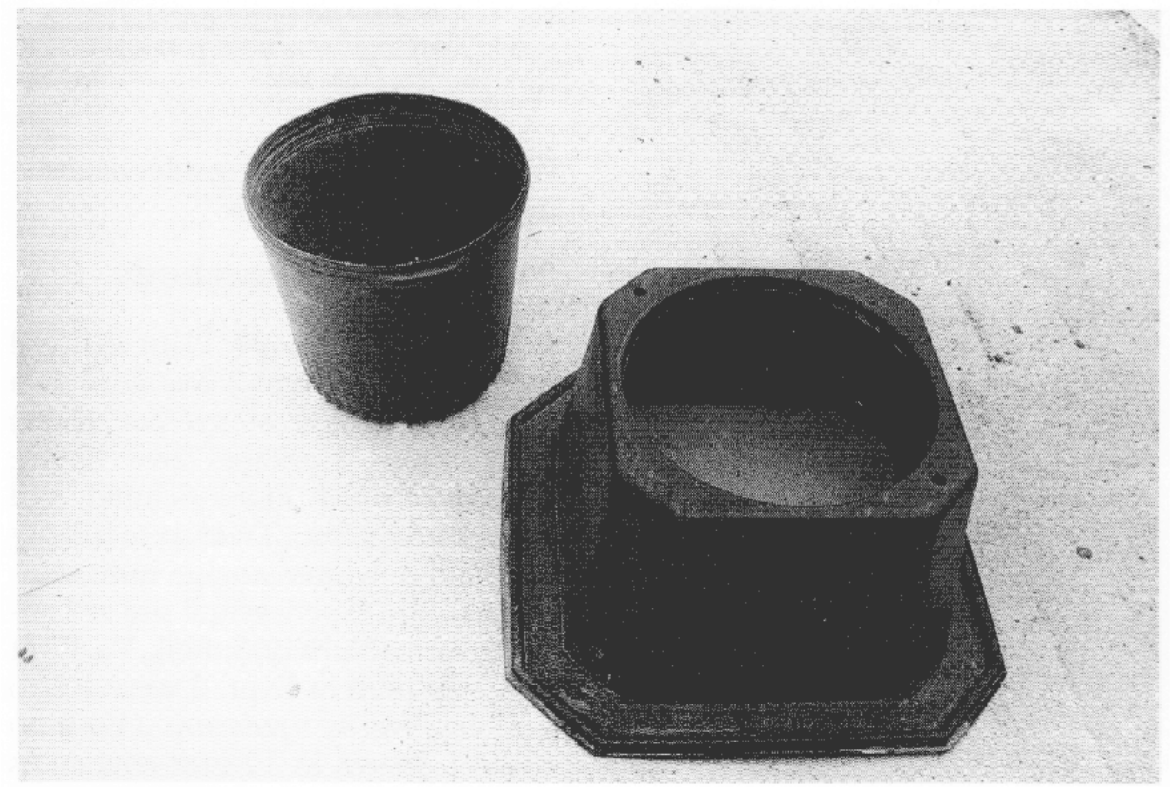

tom to just under the top lip on opposing sides of the container. Treatments included 1) no Biobarrier, without side holes, 2) no Biobarrier, with side holes, 3) Biobarrier containing eight nodules, with side holes, 4) Biobarrier containing 16 nodules, with side holes or 5) Biobarrier containing 32 nodules, with side holes. All replicates were placed in $\mathrm{P} \& \mathrm{P}$ production, and Biobarrier sheets corresponding to treatments were placed flat side down in the bottom of the socket pots, directly beneath the growing container. About $5 \mathrm{~cm}$ of space existed between the production container bottom and the Biobarrier sheets. Irrigation was supplied by micro-spray nozzles, and fertility was maintained with one application of $190 \mathrm{~g}$ of Osmocote 18-612 (O.M. Scott, Maryville, Ohio). Overall height and stem diameter of the largest main stem, taken $10 \mathrm{~cm}$ above the substrate level, were recorded at planting. On 27 July 1994 height and stem diameter were recorded again, and root escape was measured using a root rating. Roots were rated according to the number of roots which extended at least $1 \mathrm{~cm}$ beyond the production container. The rating design was $0=0$ roots, $1=1-4$ roots, 2 $=5-8$ roots, and $3=$ more than 8 roots. Root escape was evaluated in three locations: 1) through drainage holes, 2) through the bottom half (lower $50 \%$ ) section of both opposing lines of side holes, and 3) through the top half (upper 50\%) section of both opposing lines of side holes. opposing side, or no boles. of the two opposing double lines of side boles.
Fig. 3. A 56-liter production container (left) and Keeper Upper (right). Note ventilation holes on top edge of Keeper Upper.

containers and substrate similar to those in Expt. 1, except that plant-growing containers had one slit cut through each opposing sidewall (two total) with a jigsaw instead of the series of holes as in Expts. 2 and 3, in early June, 1993 at the P\&P nursery near the campus of Virginia Tech in Blacksburg, Va. There were six replicates of five treatments arranged into a completely random design. Fertility was maintained with a single application of $150 \mathrm{~g}$ of Osmocote 18-6-12. There were eight replicates arranged into a completely random design. Treatments were 1) no Biobarrier, with no side slits, 2) no Biobarrier, with side slits, 3) Biobarrier containing 10 nodules, with side slits, 4) Biobarrier containing 20 nodules, with side slits, and 5) Biobarrier containing 40 nodules, with side slits. Roots were rated on 30 July 1994 in the same reamer as in Expts. 1 and 2, except that the upper and lower sections of the side slits were combined into one reading. No shoot growth parameters were measured.

\section{Results and discussion}

Experiments 1 and 2. Neither the presence of side holes nor Biobarrier affected height, stem diameter, or a visual assessment of market quality (data not shown). Biobarrier also did not affect the number of roots escaping from the side holes (Table 1). A visual inspection of the rootballs of trees from both production systems indicated that circling roots were unaffected by treatments. Holes were drilled

Table 1. Mean root escape ratings of roots from the lower and upper sections of side holes and through bottom drainage holes of river birch grown in the pot-in-pot production system with Biobarrier sheets containing various numbers of trifluralin nodules (Expt. 1.). ${ }^{\mathrm{z}}$

\begin{tabular}{|c|c|c|c|c|}
\hline \multirow[b]{2}{*}{$\begin{array}{l}\text { Sider } \\
\text { holes }\end{array}$} & \multirow[b]{2}{*}{$\begin{array}{c}\text { Trifluralin } \\
\text { nodules }\end{array}$} & \multicolumn{2}{|c|}{ Pot-in-pot } & \multirow[b]{2}{*}{$\begin{array}{c}\text { Drainage } \\
\text { holes }\end{array}$} \\
\hline & & $\begin{array}{l}\text { Lower } \\
\text { sides }\end{array}$ & $\begin{array}{l}\text { Upper } \\
\text { sides }\end{array}$ & \\
\hline No & $\cdots$ & -- & --- & $1.7(0.06)^{w}$ \\
\hline Yes & --- & $1.4(0.06)$ & $1.3(0.07)$ & $2.6(0.04)$ \\
\hline Yes & 8 & $1.3(0.06)$ & $1.3(0.07)$ & $0.2(0.03)$ \\
\hline Yes & 16 & $1.2(0.05)$ & $1.3(0.07)$ & $0.1(0.03)$ \\
\hline Yes & 32 & $1.6(0.06)$ & $0.9(0.05)$ & 0 \\
\hline
\end{tabular}

${ }^{2}$ Root rating scored as $0=0$ roots, $1=1-4$ roots, $2=5-8$ roots, $3=$ wore than 8 roots.

${ }^{\prime} G$ rowing containers had a dowble line of holes drilled through the side walls, one double line on each

${ }^{x}$ Lowerand upper side data represent combined root ratings from each of the two lower or two upper sections

${ }^{*}$ Number in parentheses represents the standard error of the mean; $n=16$. 
Table 2. Mean root escape ratings of roots from the lower and upper sections of side holes and through bottom drainage holes of river birch grown in the Keeper Upper production system with and without Biobarrier sheets containing 32 trifluralin nodules (Expt. 2).

\begin{tabular}{lcccc}
\hline & & \multicolumn{2}{c}{ Keeper Upper } & \\
\cline { 2 - 4 } $\begin{array}{l}\text { Side } \\
\text { holes }\end{array}$ & $\begin{array}{c}\text { Trifluralin } \\
\text { nodules }\end{array}$ & $\begin{array}{c}\text { Lower } \\
\text { sides }\end{array}$ & $\begin{array}{c}\text { Upper } \\
\text { sides }\end{array}$ & $\begin{array}{c}\text { Drainage } \\
\text { holes }\end{array}$ \\
\hline No & --- & --- & -- & $2.8(0.04)^{\mathrm{w}}$ \\
Yes & --- & $0.2(0.03)$ & 0 & $2.3(0.07)$ \\
Yes & 32 & 0 & $0.1(0.02)$ & $1.3(0.08)$ \\
\hline
\end{tabular}

${ }^{2}$ Root rating scored as $0=0$ roots, $1=1-4$ roots, $2=5-8$ roots, $3=$ more than 8 roots.

${ }^{y}$ Growing containers had a double line of holes drilled through the side walls, one double line on each opposing side, or no boles.

${ }^{*}$ Lower and upper side data represent combined root ratings from each of the two lower or two upper sections of the two opposing double lines of side holes.

${ }^{w} N u m b e r$ in parentheses represents the standard error of the mean; $n=16$. through the side walls of the production container to allow the volatilized trifluralin to kill the exposed roots or to prevent their growth across the openings. The concentration of volatilized trifluralin apparently was not high enough to accomplish this. Few roots escaped from side holes in the KU system compared to the P\&P system (Table 2). This is probably because of higher humidity in the belowground environment of the P\&P system compared to the above-ground KU system. Even though the Biobarrier reduced the number of roots escaping through the drainage holes of the KU system, enough root escapes occurred to be unacceptable for commercial nurseries. The above-ground KU system does not create as tight of an overall seal as the P\&P system, in part due to the presence of ventilation holes (Fig. 3), so volatilized trifluralin likely would not be as concentrated within the space around the plant-growing container. The plant-growing container also rests directly on the ground (and therefore directly on the
Biobarrier), perhaps preventing sufficient volatilization. A ground cloth probably is needed beneath the $\mathrm{KU}$ vent root escapes from growing directly into the ground. Additional alternatives include a shorter production container to leave more room for volatilization of the trifluralin, a tighter seal between the KU and the ground, the elimination of ventilation holes to better enclose the volatilized herbicide, and Biobarrier sheets with more nodules.

All treatments that included sheets of Biobarrier essentially prevented root escape from drainage holes on P\&Pgrown river birch (Table 1). These trees were removed easily from the socket containers, with few escaping roots that would have to be cut before shipping. Several trees with no Biobarrier were rooted into the ground and could not be removed easily from the socket pots. River birch is known commonly as a species with aggressive root growth. Nontreated trees commonly have to be lifted, and the escapsystem in most circumstances to pre-

Table 3. Mean root escape ratings of roots from side slits and through bottom drainage holes of Yoshino cheery grown in a pot-in-pot production system with Biobarrier sheets containing various numbers of trifluralin nodules (Expt. 3). ${ }^{2}$

\begin{tabular}{|c|c|c|c|}
\hline \multirow[b]{2}{*}{$\begin{array}{l}S_{S i d e^{y}} \\
\text { slits }\end{array}$} & \multicolumn{2}{|c|}{ Pot-in-Pot } & \multirow[b]{2}{*}{$\begin{array}{c}\text { Drainage } \\
\text { holes }\end{array}$} \\
\hline & $\begin{array}{c}\text { Trifluralin } \\
\text { nodules }\end{array}$ & Sides $^{x}$ & \\
\hline No & --- & --- & $2.5(0.23)^{\mathrm{w}}$ \\
\hline Yes & $\cdots$ & $1.8(.27)$ & $1.9(.39)$ \\
\hline Yes & 10 & $1.7(0.51)$ & $1.7(0.52)$ \\
\hline Yes & 20 & $1.8(0.22)$ & $0.9(0.13)$ \\
\hline Yes & 40 & $2.0(0.24)$ & $0.2(0.13)$ \\
\hline
\end{tabular}

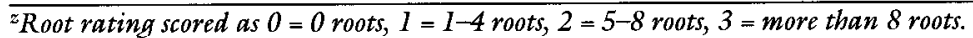

${ }^{y}$ Growing containers had single slits through the side walls extending from below the top lip to just above the bottom, one on each opposing side, or no slits.

${ }^{x}$ Data are combined root ratings for both slits per container.

"Number in parentheses represents the standard error of the mean; $n=6$. ing roots need periodic pruning during production in order to prevent the escaping roots from rooting into the ground. This increases the cost of production and compromises post-transplant performance. Nonpruned trees soon have to be discarded, and the accompanying socket pot replaced. The results of this experiment show that a sheet of Biobarrier, which includes as few as eight trifluralin nodules can be used effectively to prevent root escape from drainage holes of 56-liter river birch produced in the pot-in-pot system.

Experiment 3. Biobarrier did not affect root escape through side slits of the growing containers of Yoshino cherry (Table 3) or prevent circling roots (data not shown). Biobarrier sheets-containing 20 or 40 trifluralin nodules resulted in fewer root escapes through drainage holes of the growing containers compared to other treatments. Root escape decreased with increasing rates of Biobarrier, with nearly complete control at the 40nodule treatment. This is in contrast with river birch (Expt. 1) in which control of root escape was similar for all treatments. It is not known if these differences are species-specific or due to differences in durations of exposure. The river birch trees at Lancaster Farms Nursery were in production for only 5 months, whereas the Yoshino cherry trees at Virginia Tech were in production for about 14 months. Both species had just reached salable size. The sheets containing eight trifluralin nodules resulted in acceptable levels of control for the river birch, but the 10 nodule sheets used under the Yoshino cherry did not. For production cycles that require more than one growing season, sheets containing $>10$ nodules may be required. Similar to Expts. 1 and 2, all treatments were ineffective in preventing circling roots.

These experiments were conducted with two species and for one production cycle only. Other species need to be tested in the future to establish effective species-specific rates of Biobarrier. According to the manufacturer, Biobarrier will last up to 50 years when buried in soil at 20C. The useful life of Biobarrier under P\&P conditions should be investigated.

Root escape through drainage holes of production containers must be controlled for efficient wholesale production of pot-in-pot nursery crops. 


\section{RESEARCH UPDATES}

The results of these experiments indicate that chemical control can be accomplished with Biobarrier sheets containing as few as eight nodules of trifluralin for river birch in a one-season production cycle. Although commercially acceptable control was achieved with Biobarrier sheets containing 20 nodules, sheets containing 40 nodules were required to give control for Yoshino cherry (root rating $=0.2$ ) in a two-season production cycle similar to that for river birch in a single-season production cycle.

\section{Literature Cited}

Appleton, B.A. 1993. Nursery production alternatives for reduction or elimination of circling tree roots. J. Aboricult. 19(6):383388.

Knight, P.R., D.J. Eakes, C.H. Gilliam and J.A. Reeder. 1992. Root control techniques for the urban landscape. Proc. SNA Res. Conf. 37:39-41.

Parkerson, C.H. 1990. P\&P: A new filledtype nursery operation. Proc. Intl. Plant Prop. Soc. 40:417-419.

Ruter, J.M. 1993. Growth and landscape performance of three landscape plants produced in conventional and pot-in-pot production systems. J. Environ. Hort. 11(3):124-127.

Ruter, J.M. 1994. Use of biobarrier for control of rooting-out of pot-in-pot production systems. Proc. SNA Res. Conf. 39:108-109.

Warren. S.L. and F.A. Blazich. 1991. Influence of container design on root circling, top growth, and post-transplant root growth of selected landscape species. J. Environ. Hort. 9:141-144.

Yeager, T., C. Larsen, R. Newton, and J.C. Tort. 1994. Container production systems for pine. Proc. SNA Res. Conf. 39:78-79. 